\title{
シロネズミの予備飼育実験によるテクスグランの一考察 (I) A Study of Texgran through a Preliminary Experiment of Feeding Rats (1)
}

（昭 和 44 年 8 月 29 日受 理）

\begin{tabular}{|c|c|}
\hline $\begin{array}{c}\text { 白 } \text { 田 } \\
\text { (Kichi Shirata) }\end{array}$ & $\begin{array}{l}\text { 安斉 弶 子* } \\
\text { (Kyoko Anzai) }\end{array}$ \\
\hline $\begin{array}{l}\text { 齐 藤 好 枝* } \\
\text { (Yoshie Saito) }\end{array}$ & $\begin{array}{l}\text { 鈴 木 昭 子* } \\
\text { (Akiko Suzuki) }\end{array}$ \\
\hline
\end{tabular}

The subject of this report is meatless meat which is now attracting much attention as an economical source of protein. A price comparison and a sensory test were proceeded. $50 \%$ of texgran imported from the USA was used in stead of beef and pork diet. At the same time a preliminary experiment with feeding Wister Albino white rats was proceeded. Considerably good results were obtained from these experiments.

As for the sensory test, there was no difference between the meatless meat and the usual beef or pork. Besides the price of the meatless meat is as cheap as $1 / 3$ or $1 / 4$ of that of beef and pork. It is most suitable for quantity feeding or for home cooking. The result of the preliminary experiment of feeding six-weeks old rats for twelve weeks was as follows. There was no significant difference of feed efficiency, the weight of the internal organs, bones, calcium, blood serum protein, blood sugar and liver crude fat. However, significant differences were observed in the quantity of blood serum cholesterol and liver xanthine oxidase activities.

The fact that there is a decrease in the quantity of cholesterol when meatless meat is used in stead of $50 \%$ of the beef and pork shows that meatless meat may have significance as a preventive food for high blood-pressure and heart desease.

緒 言

わが国における動物性蛋白質の揘取量は，かなり多く なってきたが, 内容的にみると必ずしも满足な状態で はない。良質の蛋白質の摂取率は，欧米諸国に比べると その半分程度である。しかし, 欧米諸国においては獣 内の摄取と,これに伴う脂肪の過剩㩒取によるふとりす ぎと, コレステロールによる高血压, 心臓病の予防のた め, 近年, 大豆を主原料とする人工肉の研究が盛んにな り, 種々の食品が販売されており, わが国においても, 人工肉の利用が注目されてきた。それで今回は，米国輸 入のテクスダランを牛豚肉 $50 \%$ のかわりに用いて，実 際に調理し, 官能・暂好テスト，栄養比較を行なうと同 時に, ウィスター系幼シロネズミを用いた予供飼育実験 により，かなり良好な成績をえたので報告する。

\section{実験方法}

（1）官能・輓好テスト

パネルは, 本学家政学科食物栄養コースの学生より選

*桜の聖母短期大学
抜した50名によって行ない, 方法は 2 点比較法, 採点法 風味側描法などを適宜採用した。

（2）栄養比較扣よび価格の比較

実際に調理したカレーライス,ミートソースにつき, 栄養価, 価格の此較を行なう。

(3) シロネズミの予備飼育実験法

生後 6 週間の同腹のウィスター系幼シロネズミ9匹を Diet I は雄 3 匹雌 2 匹, Diet II は雄 3 匹雌 1 匹の 2 種の飼料群にわけ, 平均室温 $21^{\circ} \mathrm{C}$, 最高 $24^{\circ} \mathrm{C}$, 最低 $18^{\circ}$ $\mathrm{C}$, 湿度 $52 \% て ゙ 12$ 週間飼育した。飼料, 水は自由に摂取 せしめた。食慨組成は図1のようである。

各群のネズミの体重，および食箃の摂取量を 1 週間ご とに測定し，成長状態を検討し，飼料効寗を測定した。

12週間目に, エーテル麻酔により屠殺し, 血清コレス テロール, 血糖, 血清蛋白, 肝キサンチンオキシダーゼ の活性度, 肝粗脂肪量, 後右脚の Ca 量, 骨の重量, 長 さを測定し，检討した。血清コレステロールは， $\mathrm{ZaK}-$

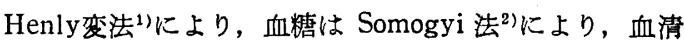
蛋白はアタゴ血清蛋白計により, 肝キサンチンオキシダ 一ゼの活性度は村松氏らの方法により, 肝粗脂肪量は 
図 1 食慨組成

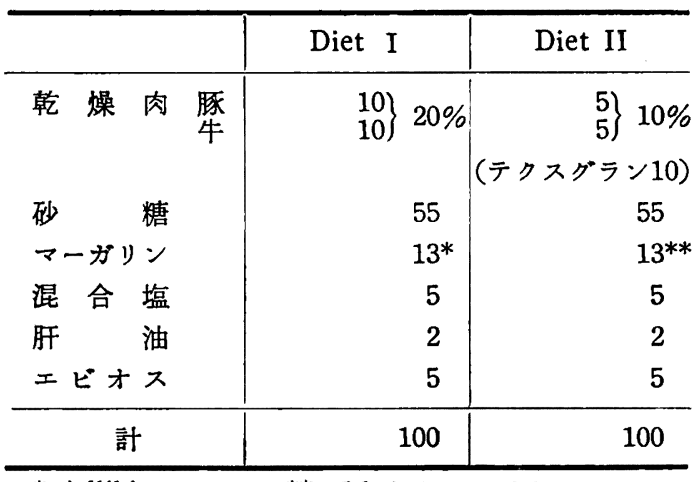

* Adlibitum

*雪印ネオマーガリン

Soxhletの常法により, Ca の定量は過マンガン酸カリの 滴定法により行なった。

\section{実験結果とその成績および考察}

人工肉を調理する際, 人工肉 $100 \%$ の場合は, 調味料, 香辛料が適当ならば，牛豚肉などの普通肉との差異を感 じさせないが，肉自身の旨味をかみしめて食するような 昜合には差がでる。ゆえに，人工肉テクスグランと牛豚

図 2 官能検査成績

\begin{tabular}{|c|c|c|c|}
\hline & 風 味 & 舌ざわり & 外観・色沢 \\
\hline 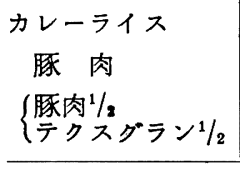 & $\begin{array}{l}\text { おいしい } \\
\text { 旨味がと } \\
\text { ぼしい }\end{array}$ & $\begin{array}{l}\text { 弾力性がある } \\
\text { ややざらざら } \\
\text { した感じ }\end{array}$ & $\begin{array}{l}\text { 全体につやが } \\
\text { ある } \\
\text { 市がなく } \\
\text { 白っぽい感じ }\end{array}$ \\
\hline 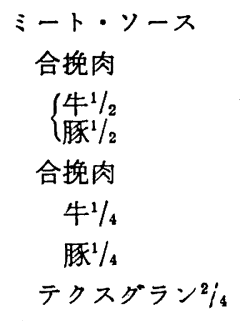 & 淡白な味 & $\begin{array}{l} \\
\text { 弾力はあるが } \\
\text { ざらざらした } \\
\text { 感じ }\end{array}$ & $\begin{array}{l} \\
\text { 水気がなくぱ } \\
\text { さぱさした白 } \\
\text { っぽい感じ }\end{array}$ \\
\hline
\end{tabular}

図 3 嘴好調査成績

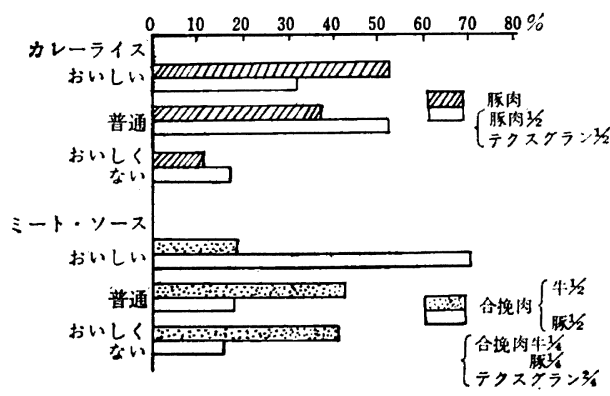

困 4 調理例にみられる栄養価の比較

Cal 蛋白質 $\mathrm{g}$ 脂肪 $\mathbf{g} \mathrm{Ca} \mathrm{mg}$

\begin{tabular}{lrrrrr}
\hline カレーライス & & & & & \\
豚(モモ肉) & $40 \mathrm{~g}$ & 112 & 6.7 & 9.2 & 1.6 \\
テクスグラン & $40 \mathrm{~g}$ & 43 & 6.8 & 0.2 & 35.0
\end{tabular}

（固型分13.2 g )

カレーライス 1 人分（調味料その他を含む）

\begin{tabular}{|c|c|c|c|c|c|}
\hline 豚（モモ肉） & $20 \mathrm{~g}$ ) & $78^{*}$ & $6.8^{*}$ & 4. $7^{*}$ & 18. $3^{*}$ \\
\hline テクスグラン & $20 \mathrm{~g}$ & 911.5 & 30.4 & 27.3 & 62.2 \\
\hline 豚（モモ肉） & $40 \mathrm{~g}$ & 945.2 & 30.3 & 31.6 & 45.5 \\
\hline
\end{tabular}

ミート・ソース

合挽 肉 $40 \mathrm{~g} \quad 142 \quad 5.9 \quad 13.0$

ミート・ソース 1 人分（調味料その他を含む）

\begin{tabular}{|c|c|c|c|c|c|}
\hline $\begin{array}{l}\text { 合婏肉 } \\
\text { テクスグラ }\end{array}$ & $\left.\begin{array}{l}20 \mathrm{~g} \\
20 \mathrm{~g}\end{array}\right\}$ & $\begin{array}{l}93^{*} \\
670\end{array}$ & $\begin{array}{l}6.4^{*} \\
21.1\end{array}$ & $\begin{array}{l}6.6^{*} \\
23.6\end{array}$ & $\begin{array}{l}18.8^{*} \\
78.0\end{array}$ \\
\hline （固型 & $6.6 \mathrm{~g})$ & & & & \\
\hline 合挽 肉 & $40 \mathrm{~g}$ & 719 & 21.0 & 30.7 & 61.8 \\
\hline
\end{tabular}

*調味料その他は含まない

肉とを, $50 \%$ ずつ混合し，ミートソース，カレーライス などの肉自身の旨味が料理を左右しない調理法を選び調 理し, 官能・嗜好テストを行なって, 図 2 , 図 3 のごと き結果をえた。全体的にみると，調理の際に味つけを考 虑すれば，両者の差は少なくなると考えられる。つぎに 因 4 に見られるごとく，栄養価を比較してみると，力口 リ一, 脂肪は牛豚肉が，人工肉よりまさっているが，蛋 白質 $\mathrm{Ca}$ 量では, 人工肉テクスグラン $50 \%$ 方がまさっ ている。ゆえに，テクスグラン $50 \%$ を，牛豚等の普通肉 50\%のかわりに使用する際，不足になりがちなカロリ一 と脂肪を，調理の際に植物油を使用する調理法をえらぶ ことによって，動物脂の弊害を伴わずに，その不足を補 足しえるのではないかと考えられる。その上，価格す東 北の小都市福島での小売価格で比較すると, 牛豚肉等普 通肉の $1 / 3 \sim 1 / 4$ 程度で経済的であり, 集団給食, 家庭料 理に最適と考えられる。

シロネズミの予備飼育実験の結果をみていくと, その 成長曲線は図 5 のよ5でオリエンタル固型飼料による ネズミの成長を上まわっており，その結果を，統計処理 すると，いずれす発有が良好で，有意差はなく，また， 飼料効率す図 6 の如く, 雨者に有意の差がみられなかっ た。

剖検の結果は, 内藏の重量は図 7 のようで,それぞれ 良好で有意差はなく，また，测定成續は四 8 のよ5で血 糖, 血清蛋白, 肝粗脂肪量には, 有意差がみられなかっ たが，血清コレステロール，肝キサンチンオキシダーゼ 
因 5 成長曲線

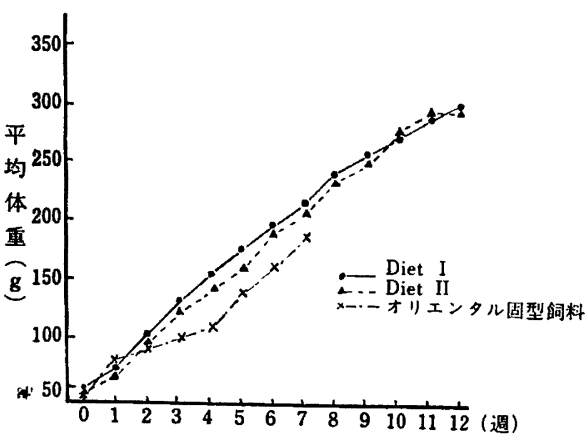

図 6

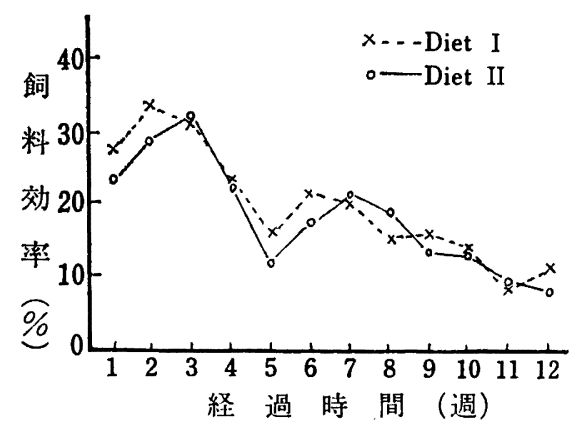

因 7 身長および臓器の重量（平均値）

\begin{tabular}{|c|c|c|c|c|c|}
\hline & 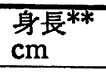 & $\begin{array}{c}\begin{array}{c}\text { 肝臟 } \\
\mathrm{g}\end{array} \\
\end{array}$ & $\begin{array}{l}\text { 心臓 } \\
\mathbf{g}\end{array}$ & $\begin{array}{l}\text { 㓏臓*** } \\
\end{array}$ & $\begin{array}{c}\text { 脾臓 } \\
\end{array}$ \\
\hline Diet I & $\begin{array}{l}18.6 \\
\pm 1.4^{*}\end{array}$ & $\begin{array}{r}11.32 \\
\pm 3.19\end{array}$ & $\begin{array}{r}1.08 \\
\pm 0.24^{*}\end{array}$ & $\begin{array}{c}1.27 \\
\pm 0.34^{*}\end{array}$ & $\begin{array}{r}0.47 \\
\pm 0.09\end{array}$ \\
\hline Diet II & $\begin{array}{l}18.8 \\
\pm 1.1^{*}\end{array}$ & $\begin{array}{r}11.35 \\
\pm 2.25\end{array}$ & ${ }^{*} \begin{array}{c}1.22 \\
\pm 0.36^{*}\end{array}$ & $\begin{aligned} & 1.22 \\
\pm & 0.25^{*}\end{aligned}$ & $\begin{array}{r}0.49 \\
\pm 0.11\end{array}$ \\
\hline $\begin{array}{l}\text { 有意差の榆 } \\
\text { 息 }\end{array}$ & $\begin{array}{l}0.8>\mathrm{P} \\
>0.7\end{array}$ & $\begin{array}{l}\mathrm{P}> \\
0.9\end{array}$ & $\begin{array}{l}0.5>\mathrm{P} \\
>0.4\end{array}$ & $\begin{array}{l}0.8>P \\
>0.7\end{array}$ & $\begin{array}{l}0.8>1 \\
>0.7\end{array}$ \\
\hline 有 意 差 & 無 & 無 & & 無 & 無 \\
\hline
\end{tabular}

の活性度には有意差がみられた。骨の長さ, 骨の重量, Ca 量は図 9 のようで，両者間に有意の差が見られなか った。

\section{要 約}

以上を要約すると，牛豚肉等普通肉 $50 \%$ のかわりに, 人工肉 $50 \%$ を使用した場合，官能・湠好テストにおいて は，両者間に差がみられず好評であり，かつまた，実際 の調理における栄養価の比較においてす, 植物油を使用 する調理法をえらぶことによって, 動物脂の慗害を伴わ ずにカロリー，脂肪の不足を補足し5ると考えられる。

因8 測 定 成 蟘

\begin{tabular}{|c|c|c|c|c|c|}
\hline & $\begin{array}{c}\begin{array}{c}\text { 血清蛋白 } \\
\%\end{array} \\
\end{array}$ & $\begin{array}{c}\text { 血清コレステ } \\
\text {-ル } \\
\mathrm{mg} / \mathrm{dl}\end{array}$ & $\begin{array}{l}\text { 血 糖 } \\
\mathrm{mg} / \mathrm{dl}\end{array}$ & $\begin{array}{c}\text { 肝 } \\
\text { 粗脂肪量 } \\
\mathrm{g} \% \\
\end{array}$ & $\begin{array}{c}\text { 肝xanthine } \\
\text { oxidase activity } \\
\text { ul } / \mathrm{h} / \mathrm{g} \\
\end{array}$ \\
\hline Diet I & $\begin{array}{l}5.97 \\
\pm 0.16^{*}\end{array}$ & $\begin{array}{c}59.8 \\
\pm 5.5^{*}\end{array}$ & $\begin{array}{c}181 \\
\pm 33.2^{*}\end{array}$ & $\begin{array}{l}4.14 \\
\pm 0.56^{*}\end{array}$ & $\begin{array}{c}220 \\
\pm 39^{*}\end{array}$ \\
\hline Diet II & $\begin{array}{l}4.79 \\
\pm 0.65 *\end{array}$ & $\begin{array}{c}51.7 \\
\pm 5.4^{*}\end{array}$ & $\begin{array}{c}178 \\
\pm 31.2^{*}\end{array}$ & $\begin{array}{l}4.79 \\
\pm 0.65^{*}\end{array}$ & $\begin{array}{r}289 \\
\pm 60\end{array}$ \\
\hline 有意差の検定 $(P)$ & $0.3>\mathrm{P}>0.2$ & $0.05>\mathrm{P}>0.02$ & $P>0.9$ & $0.2>\mathrm{P}>0.1$ & $0.05>P>0.02$ \\
\hline 有 意 差 & 無 & 有 & 無 & 無 & 無 \\
\hline
\end{tabular}

* S. D.

因 9 骨の長さ, 重量および Ca 分析值

\begin{tabular}{|c|c|c|c|c|c|}
\hline & \multicolumn{2}{|c|}{ 骨**の長さ cm } & \multicolumn{2}{|c|}{ 骨**の重量 $\mathbf{g}$} & \multirow{2}{*}{$\mathrm{Ca} \mathrm{mg} \%$} \\
\hline & 大腿骨 & 脛骨と腓骨 & 大腿骨 & 脛骨と腓骨 & \\
\hline Diet I & $\begin{array}{l}3.10 \\
\pm 0.27^{*}\end{array}$ & $\begin{array}{c}3.31 \\
\pm 0.26^{*}\end{array}$ & $\begin{array}{c}0.34 \\
\pm 0.09 *\end{array}$ & $\begin{array}{c}0.35 \\
\pm 0.05^{*}\end{array}$ & $\begin{array}{r}22.14 \\
\pm 0.39 *\end{array}$ \\
\hline Diet II & $\begin{array}{l}2.96 \\
\pm 0.15^{*}\end{array}$ & $\begin{array}{l}3.26 \\
\pm 0.22^{*}\end{array}$ & $\begin{array}{c}0.39 \\
\pm 0.07^{*}\end{array}$ & $\begin{array}{c}0.32 \\
\pm 0.04^{*}\end{array}$ & $\begin{array}{r}22.27 \\
\pm 0.69^{*}\end{array}$ \\
\hline 有意差の検定 $(P)$ & $0.4>P>0.3$ & $0.8>P>0.7$ & $0.6>P>0.5$ & $0.5>P>0.4$ & $0.8>P>0.7$ \\
\hline 有 意 差 & 無 & 無 & 無 & 無 & 無 \\
\hline
\end{tabular}


また, シロネズミの体重增加状態, 飼料効事, ならびに 剖㭘の結果の測定成責, 内臟の諸重量, 骨の発有状熊, その重量, $\mathrm{Ca}$ 量の測定においても，血清コレステロー ル, 肝キサンチンオキシダーゼの活性度をのぞいて, 有 意の差は見られなかった。

ゆえに，人工肉が良質の蛋白源食品として，栄養価高 く，しかる，おいしく，経済的な食品としてたけけてなく 高血王, 心䑏病の予防食餌としての意義があるのではな いかと考えられる。
なお，現在，オリエンタル固型飼料によるネズミの測

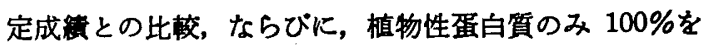
使用したときとの相違, 牛豚等の普通肉と人工肉との相 乗効果について検討中である。

文献

1) 丹羽正治, 北村元仕, 紊藤正行 : 臨床化学分析III 72 (1966)

2）柳沢文正：光電比色計の実腙，82(1964) 